\title{
New record of the starry flying gurnard, Dactyloptena peterseni (Scorpaeniformes; Dactylopteridae); from Wadge Bank, Southwest coast of India
}

\author{
K. Karuppasamy ${ }^{1}\left(\mathbb{D} \cdot\right.$ S. Davidkingston ${ }^{2} \cdot$ P. Jawahar ${ }^{1} \cdot$ L. Ranjith $^{3} \cdot$ \\ A. Kathirvelpandian ${ }^{4} \cdot$ S. Aanand ${ }^{1}$
}

Received: 16 April 2016/Revised: 29 July 2016/Accepted: 25 June 2018

(C) The National Academy of Sciences, India 2018

\begin{abstract}
Five specimens of dactylopterids measuring 220.5-320.0 mm standard length caught commercial trawler fishing in 80-120 m deep waters of Wadge Bank off Kanyakumari coast (8.02 N, 76.80 E) were collected from the landing centre at Jeppiaar fishing harbour, Muttom, Southwest coast of India. The specimens were identified as Dactyloptena peterseni (Nystrom, 1887) on the basis of morphometric measurements and the key identification character like absence of second free spine between the occipital and the first dorsal spine. The occurrence of the species suggests that the extended distribution of $D$. peterseni to Southwest coast of India. The detailed morphometric and meristic characters are described and discussed in this paper. Molecular identification was done by using partial sequence of mitochondrial cytochrome oxidase sub-unit I gene for confirmation of the species.
\end{abstract}

Keywords Dactylopterids · Flying/helmet gurnards . Kanyakumari coast · Distribution

K. Karuppasamy

karuppasamymfsc@gmail.com

1 Fisheries College and Research Institute, TNFU, Thoothukudi, Tamil Nadu 628 008, India

2 Fisheries Training and Research Centre, TNFU, Parakkai, Kanyakumari, Tamil Nadu 629 601, India

3 Tuticorin Research Centre, CMFRI, Thoothukudi, Tamil Nadu 628 001, India

4 Peninsular and Marine Fish Genetic Resources, CMFRICampus, NBFGR, Kochi, Kerala 682 018, India

\section{Introduction}

The fishes of the family Dactylopteridae under Scorpaeniformes [1-3], are commonly called as flying gurnads or helmet gurnards as there is no actual flight and are heavy bodied and beautiful coloured demersal species [1, 4]. Dactylopterids are mostly distributed in tropical and subtropical seas [5] and are usually of little commercial importance, but they are often taken as bycatch in nearshore fisheries and few species are used in marine aquarium, such as Dactyloptena orientalis [6]. The Jordan and Richardson [7] erected the two genera namely Dactyloptena and Dactylopterus comprising seven valid IndoPacific species. The genera Dactylopterus possess two dorsal fin spines adjacent to each other and about equal length whereas, one or two separate free dorsal fin spines are well separated from remainder of spinous dorsal fin in case of Dactyloptena [8]. The genus Dactylopterus is represented by a single species Dactylopterus volitans (Linnaeus, 1758) and the genus Dactyloptena contain six valid species viz., D. orientalis (Cuvier, 1829), D. macracantha (Bleeker, 1855), D. peterseni (Nystrom, 1887), D. tiltoni Eschmeyer, 1997, D. papilio Ogilby, 1910 and D. gilberti Snyder, 1909 [9, 10]. Dactyloptena peterseni could be distinguished from the closely related species $D$. orientalis by the absence a second free spine between the occipital spine and the first dorsal fin [11].

Smith [12] has recorded $D$. peterseni in the Pacific Ocean; while Silas (1965) reported the species from west coast of India (does not specify the exact location) [11], Salvi and Deshmukh [6] reported from Mumbai, Northwest coast of India. Present finding of occurrence of Dactyloptena in the Wadge Bank, Southwest coastdepicts the extended distribution range for the species in Indian waters. 
Five specimens measuring 220.5-320.0 mm standard length (SL) were collected from commercial multiday trawler operated from Jeppiaar fishing harbour, Muttom during August 2015. The specimens were caught approximately $42-60 \mathrm{~km}$ towards south off Muttom waters (8.02 $\mathrm{N}, 77.80 \mathrm{E}$ ) at the depth ranging from 80 to $120 \mathrm{~m}$ in the Wadge Bank (Kanyakumari-Vizhinjam) Southwest coast of the country (Fig. 1). The fresh specimens were photographed and the field diagnostic characters were noted for further identification (Fig. 2). The specimens were brought to the laboratory of Fisheries College and Research Institute, Thoothukudi for detailed taxonomic examination. The identification characters i.e. morphometric measurements and meristic counts were carried out based on the available standard taxonomic literature [2, 8, 10] was given in Table 1. Molecular confirmation of the species was carried out by analysing partial mtDNA COI gene. The genomic DNA was extracted using Qiagen Kit as per manufacturer's protocol. The partial sequence of cytochrome oxidase sub-unit I gene was amplified using primers COI F (5'-TCA ACC AAC CAC AAA GAC ATT GGC AC-3') and COI R (5'-TAG ACT TCT GGG TGG CCA AAG AAT CA-3') [13]. The amplifications were

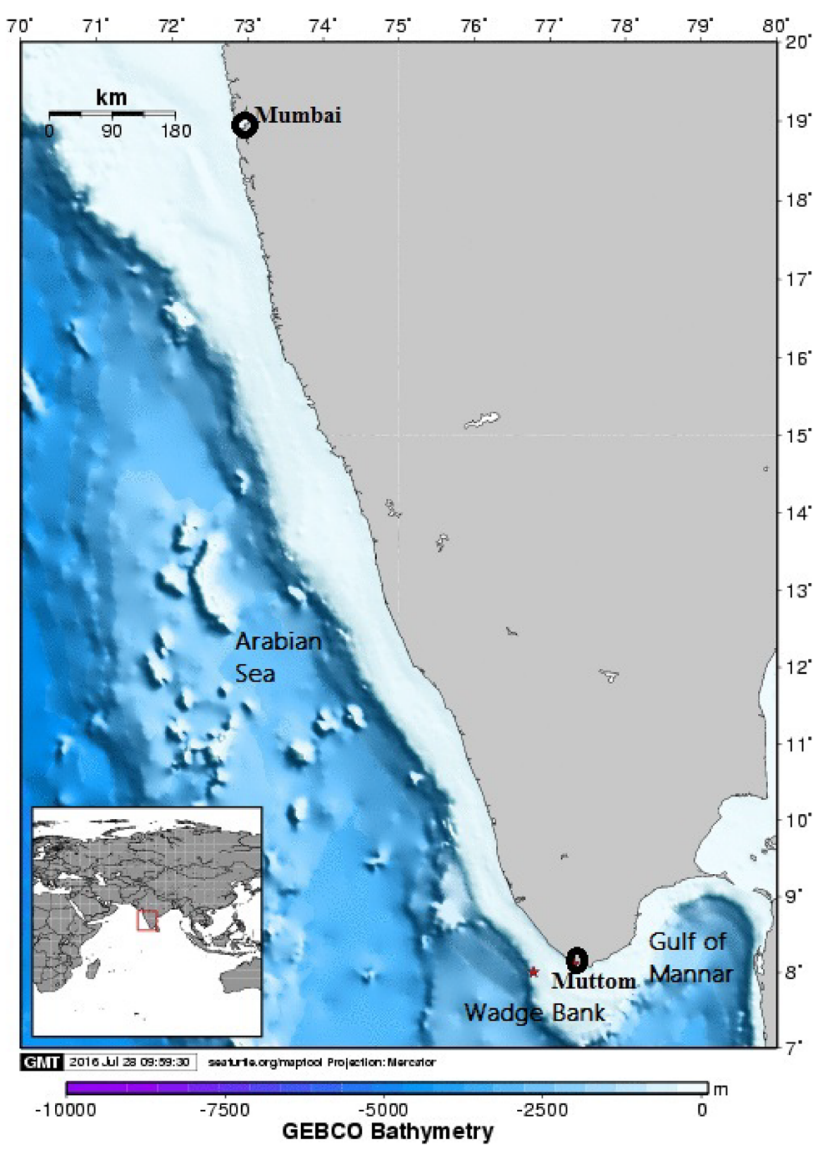

Fig. 1 Location of D. peterseni caught off Wadge Bank, Southwest coast of India. Red star: caught location performed in $25 \mu \mathrm{l}$ reactions containing $10 \times$ assay buffer (100 mM Tris, $500 \mathrm{mM} \mathrm{KCl,} \mathrm{0.1 \%} \mathrm{gelatin,} \mathrm{pH}$ 9.0) with $25 \mathrm{mM} \mathrm{MgCl}_{2}, 5 \mathrm{pmol}$ of each primer, $200 \mu \mathrm{M}$ of each dNTP1 5U TaqDNA polymerase and $20 \mathrm{ng}$ of template DNA. The following PCRconditions were used: initial preheat at $95{ }^{\circ} \mathrm{C}$ for $5 \mathrm{~min}$, denaturation $94{ }^{\circ} \mathrm{C}$ for $30 \mathrm{~s}$, annealing $508^{\circ} \mathrm{C}$ for $45 \mathrm{~s}$, extension $72{ }^{\circ} \mathrm{C}$ for $1 \mathrm{~min}$, repeated for 30 cycles, followed by a final extension for 10 min at $72{ }^{\circ} \mathrm{C}$. PCR products were sequenced in Applied Biosystems AB3730 XL capillary sequencer at the sequencing facility. The DNA sequence developed in the present study for $D$. peterseni and available sequences in the NCBI database for the species (NCBI accession Nos. JQ681400.1, KP266768.1) and closely related species, D.orientalis (NCBI accession No. FJ583311.1) were aligned and edited using BioEdit sequence alignment editor version 7.0.5.2 (Hall, 1999). Phylogenetic and molecular evolutionary analysis using Kimura 2-parameter method [14] was conducted using MEGA version 6.0 [15]. The sequence of Pomadasys maculatus (NCBI accession Nos. JX042221.1) was taken as outgroup for phylogenetic analysis. The evolutionary status was inferred using the Neighbor-Joining method [16].

Based on the key diagnostic identification characters from available taxonomic literature and also from the molecular analysis, the specimens were identified as $D$. peterseni (Nystrom, 1887). The specimen accession (FF.S.D1-02) was got from Fisheries College and Research Institute, Thoothukudi, Tamil Nadu Dr. J. Jayalalithaa Fisheries University.

Kingdom: Animalia, Phylum: Chordata, Class: Actinopterygii, Order:Scorpaeniformes, Family: Dactylopteridae Rafinesque, 1810, Genus: Dactyloptena Jorden and Richardson, 1908, and Species: Dacyloptena peterseni (Nystrom, 1887).

Body description is as follows; Body, moderately elongated. Head broad and depressed; snout rounded and depressed, eyes large; scales, each with a strong median ridge, three enlarged keel like scales were present on the lower side of posterior part of trunk with the first one originating above the middle of anal fin. Single long, prominent spine was present at angle of the preopercle. Spinous and soft dorsal fins were separated by a deep notch. Single elongate filamentous spine was widely separated from remainder of spinous dorsal fin that had with VII spines. Soft dorsal fin had 8 rays and anal fin had 6 soft rays. Caudal fin was emarginated. Pectoral fins with dark ocellus about one-third out on fin; Bases of pectoral fins divided into short anterior part with 5 rays and a long posterior part with 25-27 rays. Lateral line was absent. Body of all the specimens was reddish above and pinkish with white colour below. An oblong black blotch over middle of pectoral fins was present. All the observed five 
Fig. 2 Dactyloptena peterseni caught from Wadge Bank, Southwest coast of India

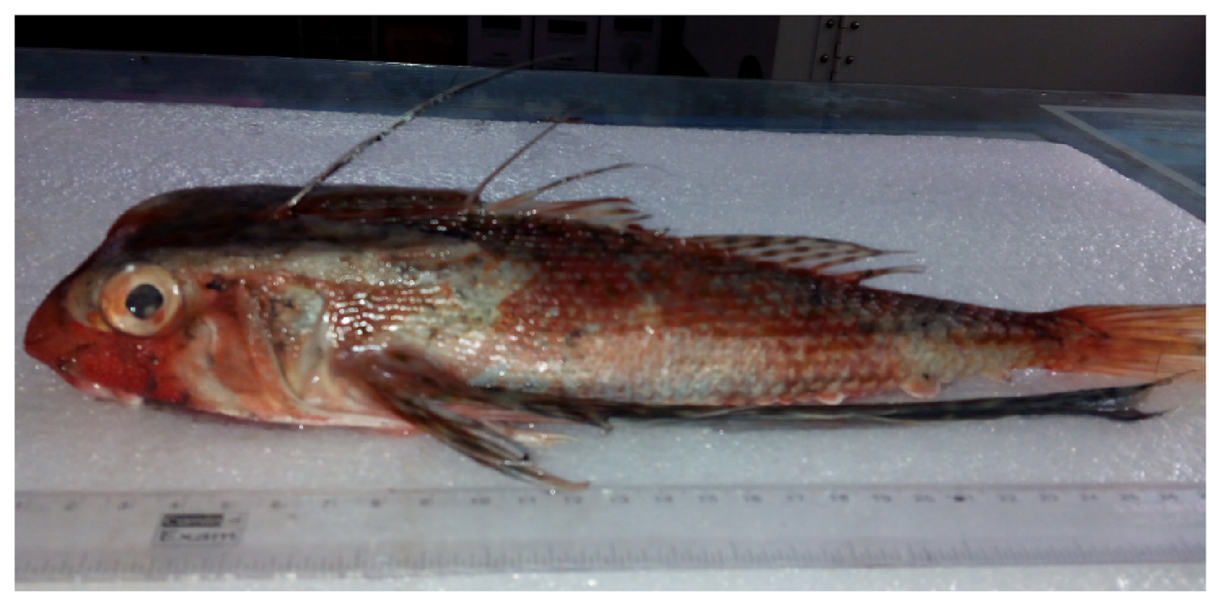

(a) Lateral view of D. peterseni

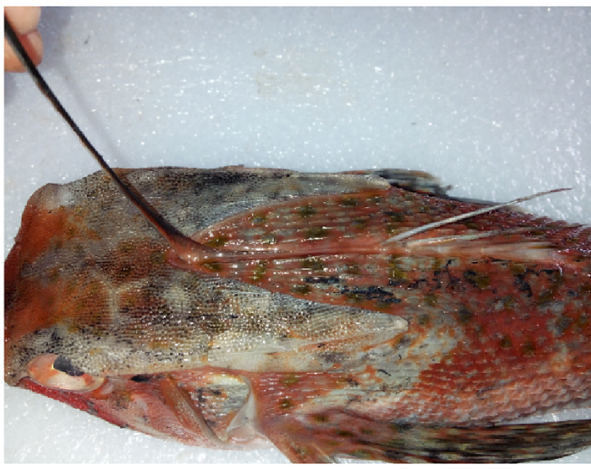

(b) Dorsal view of $D$. peterseni showing the absence of second dorsal filamentous spine.

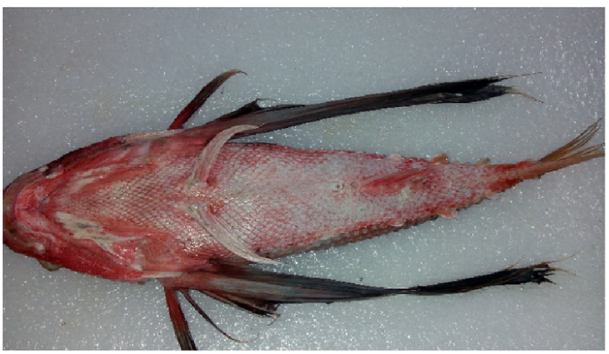

(d) Ventral view of $D$. peterseni

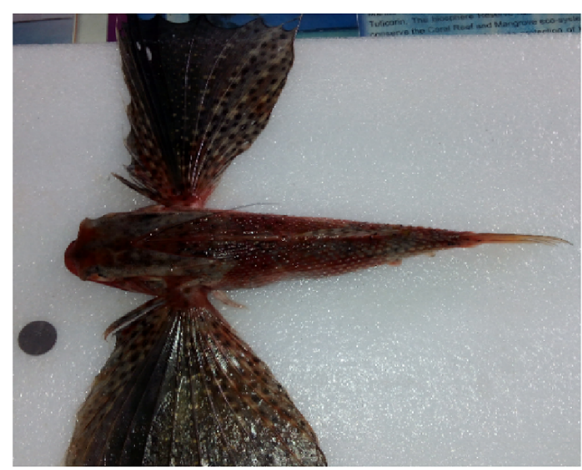

(c) Birds eye view of $D$. peterseni showing the dark occellus

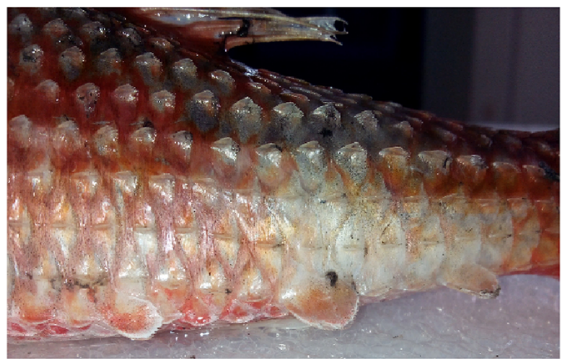

(e) Lateral view of $D$. peterseni showing the laterally enlarged keel-like scales specimens has black colour dots on the upper side of the head and body. Last dorsal fin rays also possess black dots. Mouth was moderately small mouth, sub terminal, and protractile. Upper jaw largely was obscured by bones surrounding eye. Nodular teeth was present on jaws. Small teeth on vomer and palatines was also present. Four pairs of gill arch with ten numbers of short and blunted rackers were found only in the centre of the gill arch.

This species has been reported in deeper waters ranging from 50 to $210 \mathrm{~m}$ distributed in the Japan, Indian Ocean to east Africa and Western Australia [8]. D. peterseni is closely similar to D. macracantha while there isthe absence of the second dorsal fin spine in D. peterseni whereas it is present in D. macracantha. Moreover, alarge dark spot is present on the first third of the pectoral fin in D. peterseni and in D. macracantha, a well-marked punctuated pale spots halfway out on the pectoral fins was noticed. Dactyloptena tiltoni also have the similar characters withabsence of second dorsal fin but no spots on upper side of the head [8]. 
Table 1 Diagnostic characters of D. peterseni from Wadge Bank, Southwest coast of India

\begin{tabular}{|c|c|c|c|c|c|}
\hline Diagnostic characters & Specimen-1/mm & Specimen-2/mm & Specimen-3/mm & Specimen-4/mm & Specimen-5/mm \\
\hline Total weight(g) & 540 & 455 & 613 & 444 & 360 \\
\hline \multicolumn{6}{|l|}{ Morphometric characters } \\
\hline Total length (mm) & 370 & 320.7 & 390 & 320.5 & 280.5 \\
\hline Standard length & 300.5 & 260.5 & 320 & 290 & 220.5 \\
\hline Body depth & 42.29 & 43.8 & 50.8 & 44.8 & 35.2 \\
\hline Body width & 58.36 & 50.54 & 56.8 & 54.8 & 46.5 \\
\hline Pectoral length & 20.21 & 210.5 & 220.5 & 210.5 & 180.5 \\
\hline Pelvic length & 55.31 & 48.8 & 58.79 & 52.7 & 44.6 \\
\hline Head length & 108.15 & 100.9 & 111.1 & 97.52 & 83.2 \\
\hline Eye diameter & 6.26 & 5.5 & 6.4 & 6.3 & 6.7 \\
\hline Orbit diameter & 3.2 & 3.3 & 3.3 & 3.88 & 2.3 \\
\hline Snout length & 51.1 & 46.4 & 50.4 & 44.47 & 40.25 \\
\hline Post eye length & 3.1 & 3.1 & 3.1 & 3.88 & 1.8 \\
\hline Predorsal length & 70.5 & 62.8 & 70.65 & 61.15 & 53.9 \\
\hline Inter orbital width & 45.78 & 37.7 & 44.9 & 40.6 & 32.7 \\
\hline inter orbital depth & 48.32 & 41.1 & 41.8 & 38.6 & 35.6 \\
\hline Prepectoral length & 95.46 & 92.5 & 23.1 & 89.8 & 68.2 \\
\hline Prepelvic length & 100.5 & 95.2 & 103 & 90.48 & 81.4 \\
\hline Preanal length & 190.5 & 170.5 & 190.5 & 170.5 & 144 \\
\hline Preanus length & 180.1 & 160.2 & 180.5 & 180.5 & 130 \\
\hline Distance between pelvic to anal & 87.5 & 79.8 & 90 & 89.1 & 67.11 \\
\hline Caudal peduncle length & 17.1 & 15.93 & 17.4 & 13.1 & 11.07 \\
\hline Caudal peduncle width & 14.5 & 14 & 14.3 & 13.2 & 11.5 \\
\hline Distance between anus to anal & 10.4 & 10.3 & 10 & 10 & 14 \\
\hline \multicolumn{6}{|l|}{ Meristic counts } \\
\hline Dorsal finrays & $1+5+1+8$ & $1+5+1+8$ & $1+5+1+8$ & $1+5+1+8$ & $1+5+1+8$ \\
\hline Anal finrays & 6 & 6 & 6 & 6 & 6 \\
\hline Pelvic finrays & 4 & 4 & 4 & 4 & 4 \\
\hline Pectoral finrays & $5+26$ & $5+27$ & $5+27$ & $5+25$ & $5+27$ \\
\hline
\end{tabular}

Dactyloptena peterseni diagnostic characters were as described by Eschmeyer [8]. Moreover, the specimens were caught in deeper area of Muttom waters (80-120 m) in Wadge Bank, Southwest coast which confirms the availability of $D$. peterseni as described by Eschmeyer (1997) [8]. Dactyloptena orientalis were usually found in the catch from trawler operating in the same area. The present specimens were caught along with $D$. orientalis in the catch. However, Silas (1965) collected quite a large number $D$. peterseni in addition to $D$. orientalis and $D$. macracantha from the west coast of India, but no other detailed information was available on D. peterseni [11]. The present observation provides the exact location of collection along with that detailed diagnostic characters and other taxonomic information about the species.

In addition, molecular analysis was carried out by amplifying mtDNA COI gene which resulted in $683 \mathrm{bp}$ length sequences. After editing and aligning the generated sequences with other sequences from NCBI yielded a total length of $642 \mathrm{bp}$ which was used for analysis. The gene sequence was submitted in NCBI gene bank and got the NCBI accession number (KX580026).

The pair wise genetic divergence value ranged from 0.2 to $0.3 \%$ between $D$. peterseni in the present study and other two published resources of the same species indicating that samples obtained in the present study is of D. peterseni only. Whereas, the value of $11.6 \%$ was obtained in comparison between $D$. peterseni and closely related species, D. orientalis. The Neighbour Joining tree (Fig. 3) also supported the above findings by revealing distinct clades where similar species were clustered under same nodes (sequences from the present study and other available resources for $D$. peterseni) while dissimilar species were 


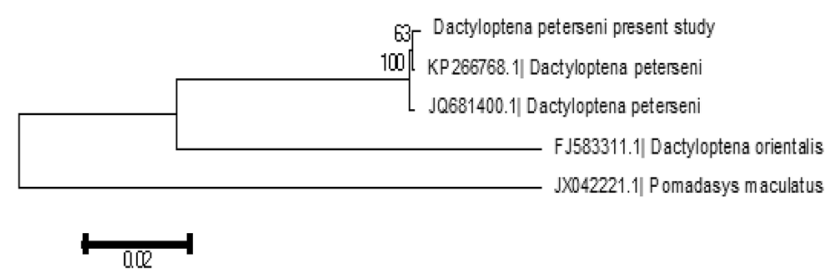

Fig. 3 NJ tree depicting the phylogenetic relationship among $D$. peterseni present study with related fish species

clustered under separate nodes (between $D$. peterseni and D. orientalis as well as Pomadasys maculatus).

The Wadge Bank (area between Kanyakumari and Vizhinjam approximately 4000 sq. miles)is a fertile ground famous for commercially important percoid fishes like rock cods, snappers etc. Moreover, the continental slope is the widest along the south and south eastern edge of the Wadge Bank, whereas the slope is gentle, precipitous beyond 500 and 180-450 $\mathrm{m}$ depth with undulating bottom topography on the eastern side of the Wadge Bank and in the Gulf of Mannar [17]. Hence, there is a scope of diverse resources in particular deep sea fishery resources along Gulf of Mannar Southeast coast [18, 19] and the Wadge Bank, Southwest coast of India.

Acknowledgement The authors are very grateful to the Tamil Nadu Dr. J. Jayalalithaa Fisheries University(TNJFU) provided the financial supports. The authors express heartfelt thanks to the Dean of Fisheries College and Research Institute, Thoothukudi for the encouragement during the course of this study. The authors also wishes to acknowledge the online GIS program MAPTOOL, provided by seaturtle.org.

\section{References}

1. Eschmeyer WN, Dempster LJ (1990) Dactylopteridae. In: Quero JC, Hureau, Karrer CA, Post and Saldanha L eds. Clofeta II. Checklist of the fishes of the eastern tropical, Atlantic. California Academy of Sciences, Vol. 2. UNESCO Paris pp 690-691

2. Washington BB, Eschmeyer WN, Howe KM (1984) Scorpaeniforms: relationships Ontogeny and systematics of fishes. Am Soc Ichthyo Herp Special Pub I:438-477
3. Nelson JS (1994) Fishes of the world, 3rd edn. Wiley, Hoboken

4. Hubbs CL (1933) Observations on the flight of fishes, with a statistical study of the flight of the Cypselurinae and remarks on the evolution of the flight fishes. Pap Mich Acad Sci Arts Lett 17:575-611

5. Eschmeyer WN, Fong JD (2016) Species of Fishes by family/subfamily electronic database accessible at http://research.calacademy.org/research/ichthyology/catalog/ SpeciesByFamily.Html. Accessed 22 Jan 2016

6. Salvi PS, Deshmukh VD (1965) Landings of flying gurnard in Mumbai. Mar Fish Infor Serv Techn Ext Ser 205:20

7. Eschmeyer WN (1986) Family no. 159: dactylopteridae. In: Smith MM, Heemstra PC (eds) Smith's sea fishes. Macmillian, South Africa. 1990. Catalogue of the genera of recent fishes. California Academy of Sciences, San Francisco, p 490

8. Eschmeyer WN (1997) A new species of Dactylopteridae (Pisces) from the Philippines and Australia, with a brief synopsis of the family. Bull Mar Sci 60:727-738

9. Jordan DS, Richardson RE (1908) A review of the flat-heads, gurnards, and other mail-cheeked fishes of the waters of Japan. Proc U S Natl Mus 33:629-670

10. Froese R, Pauly D (2016) Fish base. In: World Wide Web electronic publication. http://www.fishbase.org, version

11. Jones S (1965) Comments on the so called rare marine fishes of the genera Dactyloptena Jordan and Richardson and Lepidotrigla Gunther recently reported from Madras. Mar Biol Assoc India 7(1):124-126

12. Smith JLB (1961) The sea fishes of Southern Africa, 4th en. Cape Town

13. Ward RD, Zemlak TS, Innes BH, Last PR, Hebert PDN (2005) DNA barcoding Australia's fish species. Philos Trans R Soc Lond Ser B Biol Sci 360:1847-1857

14. Kimura M (1980) A simple method for estimating evolutionary rate of base substitutions through comparative studies of nucleotide sequences. J Mol Evol 16:111-120

15. Tamura K, Stecher G, Peterson D, Filipski A, Kumar S (2013) MEGA6: molecular evolutionary genetics analysis version 6.0. Mol Biol Evol 30:2725-2729

16. Saitou N, Nei M (1987) The neighbor-joining method: a new method for reconstructing phylogenetic trees. Mol Biol Evol 4:406-425

17. Silas EG (1965) Exploratory fishing by R.V. Varuna. Cent Mar Fish Res Inst Bull 12:1-86

18. Ranjith L, Kannan K, Joshi KK, Vinod K (2016) Range extension of the Titan Cardinalfish, Holapogon maximus (Boulenger, 1888) in the Southern Coast of India. Natl Acad Sci Lett 39(2):95-98

19. Kannan K, Ranjith L, Joshi KK, Sajan J (2014) First record of Grammonus robustus Smith and Radcliffe, 1913 (Ophidiiformes: Bythitidae) from Indian waters. Mar Biodivers Rec 7(57):1-4 